\title{
Produktivitas Kerja Pegawai yang Dipengaruhi oleh Work From Home (WFH) dan Lingkungan Kerja Selama Masa Pandemi
}

\author{
Bintang Narpati ${ }^{1}$; Indra Lubis ${ }^{2}$; Kardinah Indriana Meutia ${ }^{3}$; Endah Prawesti Ningrum ${ }^{4}$ \\ Universitas Bhayangkara Jakarta Raya \\ bintang.narpati@gmail.com; indr4lubis@gmail.com; tya@ubharajaya.ac.id; \\ endahprawestiningrum81@gmail.com
}

\section{ARTICLES \\ INFORMATION}

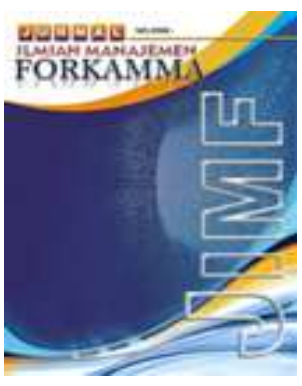

JURNAL ILMIAH MANAJEMEN FORKAMMA

$$
\begin{gathered}
\text { Vol.4, No.2, Maret } 2021 \\
\text { Halaman : } 121-133 \\
\text { C LPPM \& FORKAMMA }
\end{gathered}
$$

Prodi Magister Manajemen

UNVERSITAS PAMULANG

ISSN (online) : 2599-171X

ISSN (print) : :2598-9545

\section{Keyword :}

Work From Home, Lingkungan Kerja dan Produktivitas Kerja

JEL. classification :

O15,

\footnotetext{
Contact Author :

PRODI

MAGISTER MANAJEMEN \& FORKAMMA UNPAM

JL.Surya Kencana No.1 Pamulang

Tangerang Selatan - Banten

Telp. (021) 7412566, Fax (021) 7412491 Email :

jurnalforkamma.unpam@gmail.com
}

Tujuan dari riset ini adalah mengukur produktivitas kerja yang dipengaruhi oleh Work From Home dan lingkungan kerja selama masa pandemi pada pegawai Pemda Kota Bekasi Dinas Perumahan Kawasan Pemukiman dan Pertanahan. Analisa deskriptif kuantitatif adalah metode yang digunakan pada penelitian ini dengan responden 148 (seratus empat puluh delapan) pegawai pemda Kota Bekasi Dinas Perumahan Kawasan Pemukiman dan Pertanahan. Regresi linier ganda adalah digunakan pada riset ini. Pada hipotesis ini menduga adanya hubungan antar variable bebas yang mempengaruhi variable terikat. Penelitian ini menghasilkan secara parsial baik variable bebas "Work From Home (WFH)" atau X1 maupun "Lingkungan Kerja (X2)", "berpengaruh terhadap" variable "Produktivitas" pegawai Pemerntah Daerah Kota Bekasi.

"The purpose of this research is to measure the work productivity built by Work From Home and the work environment during the pandemic period for employees of the Bekasi City Government Housing, Settlement Areas and Land Offices". Quantitative descriptive analysis is the method used in this study with 148 respondents (one hundred and forty eight) employees of the Bekasi City Government of Housing, Settlement Areas and Land Offices. Multiple linear regression was used in this research. It is suspected that there is a relationship between the independent variables which affects the dependent variable. This research produces partially both the independent variables" Work From Home (WFH) or $X_{1}$ and the Work Environment $\left(X_{2}\right)$ ", which affect the productivity variables of the Bekasi City Government employees. 


\section{A. PENDAHULUAN}

Wabah Virus Covid-19 atau Virus Corona yeng mematikan ini telah menyebar ke seluruh dunia dan telah memakan banyak memakan korban penduduk dunia termasuk di Indonesia yang masuk sekitar bulan Maret tahun 2020. Pemerintah negara di dunia telah berusaha keras untuk mencegah meluasnya virus ini dengan berbagai cara penanggulangan termasuk mengkampanyekan akan pentingnya untuk menghilangkan virus ini dari negaranya masing-masing.

Kondisi perekonomian dunia hampir seluruhnya terpukul akibat meluasnya virus Covid-19. Tidak hanya perekonomian saja namun sudah menyebabkan banyaknya korban hampir penduduk di seluruh dunia termasuk negara Indonesia terkena dampak akibat dari virus berbahaya ini. Membatasi pergerakan aktivitas di wilayah yang terkena dampak atau PSBB akhirnya diterapkan di wilayah Indonesia untuk mengurangi penyebaran virus Covid-19 ini. Melalui kampanye 4M (Memakai masker, Mencuci tangan dan Menjaga jarak) sering dikampanyekan baik oleh pemerintah maupun masyarakat sosial lainnya dalam mencegah berjangkitnya virus yang mematikan ini.

Sebelum adanya wabah atau pandemi ini, para pegawai bekerja di kantor setiap hari namun setelah adanya virus ini, para pegawai diwajibkan bekerja di rumah (Work From Home) yang dituangkan melalui instruksi gubernur atau kepala daerah masing masing dalam menerapkan PSBB tersebut. Berdasarkan pernyataan (Bloom, 2014) dalam jurnal "To Raise Productivity, Let More Employees Work from Home" pada perusahaan "Chinese Travel Website Ctrip", menyebutkan adanya rasio pegawai di rumah dengan yang aktivitas di kantor. Disebutkan bahwa karyawan yang bekerja dari "rumah" lebih bahgia dan lebih produktif sehingga kecil kemungkian untuk berhenti bekerja.

Menurut (Himawan et al., 2020) dengan jurnal "The Sociocultural Barriers of WorkFrom-Home Arrangement Due to COVID-19 Pandemic in Asia: Implications and Future Implementation", WFH diatur dengan mengawasi dan memberikan sanksi yang tinggi kepada para pekerja, hal ini dijumpai pada negara Indonesia, Thailand, India, Cina. Menurut penelitian dari (Dingel \& Neiman, 2020) dengan judul "How Many Jobs Can be Done at Home?'. Dalam penelitian ini Jonathan I. Dingel et all mengklasifikasikan pekerjaan ke delapan puluh lima negara, yang menyatakan jika ekonomi skala rendah apat dikerjakan di rumah. Menurut (Al-Shammari, 2013) dengan jurnal T"he Effect of Work Environment on Employees" Productivitas menyatakan bahwa adanya bukti yang kuat tentang pentingnya lingkungan kerja dalam produktivitas karyawan.

\section{A. KAJIAN LITERATUR}

\section{Work From Home (WFH)}

Bentuk pekerjaan yang dilakukan dari dari rumah (WFH) diartikan sebagai pekerjaan telecommute atau telecommuter atau teleworker atau pekerjaan yang dilakukan di rumah (Wikipedia, n.d.-b). Menurut (Dictionary, n.d.) bahwa WFH digunakan dalam komunikasi digital yang menginformasikan pegawai bekerja di rumah.. Dapat ditarik kesimpulan bahwa bekerja dari rumah (WFH) adalah pegawai yang melakukan aktivitas 
atau pekerjaannay dikantor dialihkan pekerjaan tersebut dilakukan di rumah sesuai dengan instruksi dan tanggung jawab yang telah dibebankan.

Beberapa indikator bekerja dari rumah (Work From Home) yang dikutip dari jurnal (Farrell, 2017), yaitu :

1. Lingkungan kerja yang fleksibel yaitu memberikan kesempatan kepada pegawai terkait dengan tugas yang diberikan oleh atasan.

2. Adanya gangguan stress pegawai yang disebabkan permasalahan hidupnya yang mengakibatkan terhambatnya aktivitas sehari-hari..

3. Secara sosial menimbulkan kedekatan dengan anggota keluarga yang dirasakan penting bagi pegawai dalam memberikan dukungan bertugas.

4. Mengurangi atau bahkan menghilangkan waktu perjalanan ke kantor.

5. Memberikan kesehatan dan keseimbangan kerja

6. Dapat memunculkan kreativitas dalam memecahkan masalah.

7. Dapat membedakan atau memisahkan antara pekerjaan rumah dengan pekerjaan kantor.

\section{Lingkungan Kerja di Rumah}

Lingkungan yang nyaman dalam bekerja merupakan hak bagi pegawai untuk mendapatkannya. Lingkungan yang nyaman tidak hanya adanya hubungan yang harmonis antara sesame karyawan (non fisik) namun juga terkait dengan lingkungan kerja fisik yaitu sepeti ruangan yang segar bagi pegawai untuk bekerja atau adanya air conditioning (AC), pencahayaan yang disesuaikan dengan konidisi pekerjaan pegawai, keharuman ruangan dan sebagainya yang membuat pegawai merasakan atkivitas dalam bekerja tidak mengalami gangguan. Menurut (Nitisemito, 2013), lingkungan kerja mempengaruhi karyawan dalam melaksanakan tugas misalnya penerangan lampu, temperature ruangan $(A C)$ dan lain-lain.

Menurut (Jain \& Kaur, 2014) dengan jurnal berjudul "Impact of Work Environment Job" menyatakan bahwa hubungan sosial di kantor seperti membina relation dengan sesame rekan kerja, supervisor dan perusahaan bisa dipengaruhi oleh lingkungan kerja. Jurnal dengan judul "Impact of Working Environment on Job Satisfaction" oleh (Raziq \& Maulabakhsh, 2015), kepuasan kerja dipengaruhi oleh lingkungan kerja secara positif. Pernyataan dari (Chandrasekar, 2011) bahwa dalam menciptakan lingkungan kerja yang baik diperlukan peran dari organisasi agar karyawan lebih produktif dan meniingkatkan keuntungan bagi organisasi. Lingkungan kerja yang biasa dilakukan oleh pekerja di kantor namun dalam masa pandemi ini hampir seluruh pegawai yang bekerja melakukan aktivitas pekerjaannya di rumah.

Rumah adalah bangunan yang dijadikan untuk tempat tinggal dalam periode tertentu baik untuk manusia maupun hewan dalam hal ini tempat tinggal hewan adalah berupa sangkar, kendang ataupun sarang (Wikipedia, n.d.-a). Dari beberapa pendapat mengenai lingkungan kerja dan rumah disimpulkan mengenai lingkungan kerja di rumah yaitu apapun yang menyangkut dengan pekerjaan karyawan dan dilakukan di dalam bangunan tempat tinggalnya. adalah :

Menurut (Siagian, 2014), beberapa faktor yang dapat menciptakan lingkungan kerja

1. Adanya bangunan untuk melakukan aktivitas kerja

2. Adanya ruangan yang relatif besar untuk pegawai bekerja

3. Adanya pertukaran udara yang baik

4. Adanya ruang untuk tempat ibadah 
5. Adanya fasilitas untuk penjemputan pegawai

Lingkungan kerja di rumah yang dilakukan oleh pegawai dalam menjalankan tugas atau aktivitas harian di kantor memiliki situasi yang berbeda. Sebagai indikator dalam menjalankan pekerjaan di rumah, minimal suasana lingkungan di rumah diusahakan agar tidak jauh berbeda dengan lingkungan kantor, oleh sebab itu lingkungan rumah tersebut harus dalam kondisi sehat. Kelompok penilaian kesehatan perumahan sesuai "Keputusan Menteri Kesehatan RI (No. 829/Menkes/SK/VII Tahun 1999, n.d.)" yaitu :

a. komponen tempat tinggal/rumah, antara lain ventilasi, lantai, atap, tata ruang serta penerangan.

b. sarana sanitasi, antara lain tempat pembuangan sampah, air bersih, pembuangan limbah dan kotoran.

c. perilaku penghuni, antara lain membuang sampah pada tempatnya, membersihkan halaman dan rumah dan membuka jendela ruangan.

Dari teori tersebut, indikator lingkungan kerja di rumah dapat disimpulkan :

1. Adanya aktivitas pekerjaan dalam tempat tinggal

2. Adanya ruangan untuk bekerja dengan ventilasi udara yang segar

3. Adanya sarana sanitasi berupa tempat pembuangan sampah dan kotoran

4. Adanya ruangan untuk beribadah yang bersih

5. Adanya gangguan pekerjaan di luar rumah seperti wabah penyakit, ketakutan dan lain-lain.

\section{Produktivitas Kerja}

"Produktivitas kerja" adalah "ratio output berbanding dengan ratio input fisik". Menurut (Huselid, 2018) menyatakan bahwa pelatihan kerja dapat menghasilkan produktivitas kerja tinggi. Menentukan produktivitas kerja dapat ditentukan melalui sasaran atau tujuan yang obyektif, perbandingan pegawai dengan waktu, kualitas dan pengendalian pada hasil serta fasilitas bagi pegawai (Sauermann, 2016).

Berbagai macam bentuk produktivitas kerja menurut (Mulyadi, 2001) adalah :

1. Total yaitu tanpa mengukur dan mengukur pertukaran produktivitas kerja antar masukan.

2. Parsial yaitu dilakukan secara terpisah untuk satu masukan dan menghasilkan keluaran.

Ada beberapa faktor yang dapat mempengaruhi produktivitas, diataranya pekerjaan, gaji, kebutuhan karyawan, penempatan karyawan, pendidikan, lingkungan kerja, kesehatan, motivasi, faktor manajerial dan ala-alat yang digunakan. Pada perusahaan, sistem penilaian yang dilakukan terhadap pegawai adalah dengan mengukur produktivitas kerja dari seorang pegawai. Pengukuran produktivitas kerja pada pegawai akan menentukan penilaian dan mengukur prestasi kerja seorang pegawai dan dengan penilian ini dapat ditentukan untuk mempromosikan pegawai untuk kenaikan jabatan dan juga dapat memberikan perhatian dari pimpinan terhadap bawahannya. Penilaian produktivitas ini dapat juga dilihat dari factor-faktor pendukungnya yaitu loyalitas, integritas, kepemimpinan, kejujuran, tim work, dedikasi dan partisipasi pegawai.

Manfaat yang diharapkan oleh pimpinan yaitu dapat mengetahui skill dan kapabiltas masing-masing pegawai yang dijadikan acuan pada bagian Sumber Daya Manusia dalam penyempurnaan kerja seorang pegawai. Indikator produktivitas kerja menurut (Sauermann, 2016) adalah :

1. adanya target atau sasaran kerja harus objektif,

2. adanya ketersediaan fasilitas dalam bekerja bagi pekerja, 
3. adanya perbandingan pekerja dengan waktu dengan fokus dan kualitas kerja dengan fokus pada hasil

\section{Penelitian Sebelumnya}

Jurnal dari "(Simarmata, 2020) Judul: Pengaruh Work From Home Terhadap Produktivitas Dosen Politeknik Negeri Ambon". Hasilnya menunjukkan bahwa secara parsial bekerja dari rumah (WFH) memiliki pengaruh positif dan signifikan pada produktivitas kerja dosen. Menurut (Saleh, 2018) dengan Judul : "Pengaruh Disiplin Kerja, Motivasi Kerja, Etos Kerja Dan Lingkungan Kerja Terhadap Produktivitas Kerja Karyawan Bagian Produksi Di PT Inko Java Semarang". Hasil penelitiannya yaitu "lingkungan kerja hasilnya negatif dan secara signifkan tidak mempengaruhi produktivitas kerja". Sedangkan menurut (Sinaga \& Ibrahim, 2016) hasil penelitiannya yaitu "lingkungan kerja berpengaruh positif terhadap produktivitas kerja karyawan". Riset ini meneliti pada karyawan PT. Mitra Unggul Pusaka Pelalawan Riau.

\section{Gambar 1. Kerangka Berpikir}

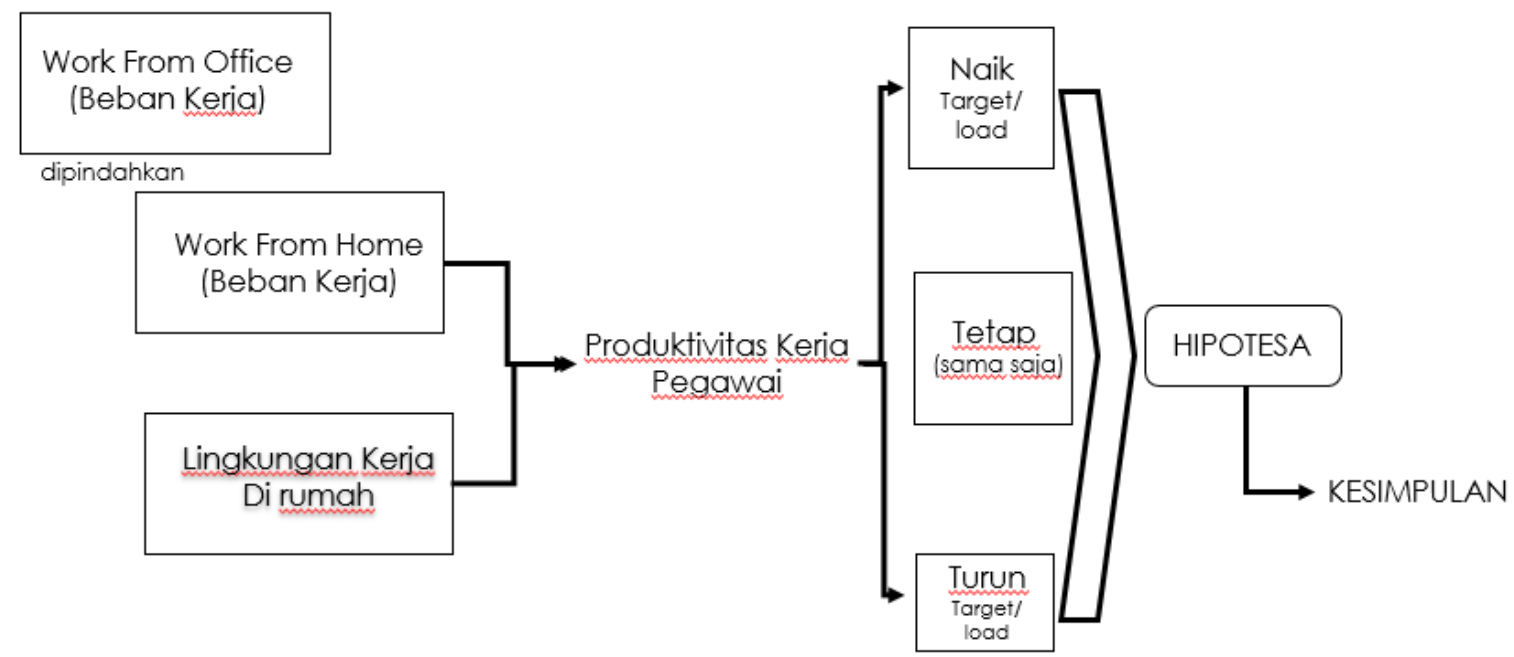

Work From Home (WFH) adalah hal yang tidak biasa terjadi setahun kebelakang ini namun karena adanya pandemi di seluruh dunia khususnya di Indonesia, menyebabkan pengalihan pekerjaan yang sebelumnya dikerjakan di kantor bergeser atau beralih pengerjaannya di rumah. Laporan ataupun tugas-tugas yang biasa dikerjakan di kantor memaksa pegawai untuk mengerjakannya dari rumah. Maksud pengalihan tugas yang biasa dikerjakan di kantor dan dikerjakan dari rumah adalah agar sasaran atau tujuan organisasi tetap tercapai atau mengukur produktivitas pegawai yang dilakukan dari rumah. Melalui pengukuran produktivitas pegawai ini dapat diketahui apakah produktivitas naik sesuai target yang diberikan atau tetap saja atau bahkan menurun dengan target yang sama diberikan pada saat pengerjaannya di kantor.

Dari pengukuran produktivitas pegawai tersebut, dapat dibuat hipotesa seperti pada gambar 2 dan selanjutnya dapat ditarik kesimpulan kerkaitan masing-masing variabel bebas terhadap variable terikatnya. 


\section{Gambar 2. Hipotesis}

\section{Hubungan variable bebas dengan terikat}

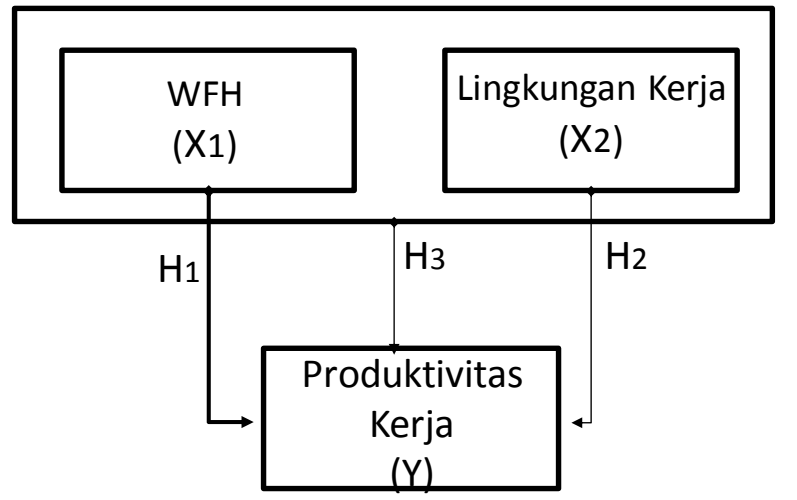

\footnotetext{
$\longrightarrow$ : Diduga ada pengaruh variabel $\mathrm{X}_{1}$ dan $\mathrm{X}_{2}$ terhadap $\mathrm{Y}$ secara parsial

---- : Diduga ada pengaruh variabel $X_{1}$ dan $X_{2}$ terhadap $Y$ secara simultan
}

\section{Pengaruh Work From Home (WFH) Terhadap Produktivitas Kerja}

Pekerjaan yang dilakukan di rumah memberikan dampak kepada produktivitas kerja. Work From Home (WFH) ini dilakukan baik karena faktor lingkungan yang secara "memaksa" mengerjakan pekerjaan tidak di kantor. Karyawan tetap menunjukkan produktivitas kerja walaupun pekerjaan yang dilakukan dirumah tidak seperti di kantor, seperti penelitian sebelumnya yang diperkuat oleh (Simarmata, 2020) bahwa produktivitas kerja dipengaruhi positif secara signifikan oleh Work From Home (WFH).

\section{Pengaruh Lingkungan Kerja Terhadap Produktivitas Kerja}

Lingkungan tempat kerja yang memberikan pengaruh dalam hal ini di rumah dapat menjadikan kenyamanan bagi karyawan untuk dapat melakukan aktivitas pekerjaan karena dapat berkumpul dengan keluarga dan dapat menghindari kemacetan di jalan. Penelitian ini diperkuat oleh (Jain \& Kaur, 2014) bahwa hasil dan produktivitas menjadi efektif namun kepuasan karyawan dan lingkungan kerja tergantung dari masing-masing organisasi.

\section{METODOLOGI PENELITIAN}

Penelitian ini menggunakan analisa deskriptif kuantitatif melalui wawancara dan penyebaran kuesioner terhadap pegawai Pemerintah Kota Bekasi Dinas Perumahan Kawasan Pemukiman dan Pertanahan dengan responden 148 pegawai. Program SPSS 24 for windows digunakan untuk menganalisa pada penelitian ini. 


\section{HASIL DAN PEMBAHASAN}

Pada tabel 1 hasil uji validitas menggambarkan masing-masing variable valid atau tidaknya. Dari hasil uji validitas baik variable bebas maupun terikat memiliki validitas karena $r$-hitung $>$ r-tabel $(0,1614)$, signifikansi $5 \%$ dan sample yang digunakan adalah $\mathrm{N}=148$.

Tabel 1.

Uji Validitas

\begin{tabular}{|c|c|c|c|c|c|}
\hline \multirow[b]{2}{*}{ Pertanyaan } & \multicolumn{3}{|c|}{$r$-hitung } & \multirow[b]{2}{*}{$\begin{array}{c}r \text {-Tabel } 5 \% \\
(\mathrm{~N}=148)\end{array}$} & \multirow[b]{2}{*}{ Keterangan } \\
\hline & WFH (X1) & $\begin{array}{l}\text { Lingkungan } \\
\text { Kerja (X2) }\end{array}$ & $\begin{array}{l}\text { Produktivitas } \\
\text { (Y) }\end{array}$ & & \\
\hline 1 & 0.663 & 0.671 & 0.765 & 0.1614 & valid \\
\hline 2 & 0.596 & 0.716 & 0.769 & 0.1614 & valid \\
\hline 3 & 0.561 & 0.560 & 0.586 & 0.1614 & valid \\
\hline 4 & 0.573 & 0.700 & 0.661 & 0.1614 & valid \\
\hline 5 & 0.589 & 0.720 & 0.534 & 0.1614 & valid \\
\hline 6 & 0.581 & 0.664 & 0.837 & 0.1614 & valid \\
\hline 7 & 0.687 & 0.622 & 0.837 & 0.1614 & valid \\
\hline 8 & - & 0.651 & 0.830 & 0.1614 & valid \\
\hline 9 & - & 0.681 & 0.803 & 0.1614 & valid \\
\hline 10 & - & - & 0.539 & 0.1614 & valid \\
\hline
\end{tabular}

Pada tabel 2 uji reliabilitas, masing-masing variable memiliki Cronbach alpha di atas 0,7 yang berarti bahwa index variable ini dapat dipercaya atau diandalkan dan dikatakan reliable.

\section{Tabel 2.}

\section{Uji Reliabilitas}

\begin{tabular}{crr} 
Variabel & $\begin{array}{c}\text { Cronbach's } \\
\text { Alpha }\end{array}$ & N of Items \\
\hline $\mathrm{X} 1$ & 0.702 & 7 \\
\hline $\mathrm{X} 2$ & 0.839 & 9 \\
\hline $\mathrm{Y}$ & 0.869 & 9 \\
\hline
\end{tabular}

Pada uji Kolmogorov - Smirnov Monte Carlo, siginifikansi sebesar 0,339 atau lebih besar dari 0,05 , dapat dikatakan bahwa penelitian ini memenuhi syarat untuk normalitas. 
Tabel 3.

Uji Normalitas - One Sample K-S Test

One-Sample Kolmogorov-Smirnov Test

\begin{tabular}{|c|c|c|c|}
\hline & & & $\begin{array}{l}\text { Unstandardiz } \\
\text { ed Residual }\end{array}$ \\
\hline$N$ & & & 148 \\
\hline \multirow[t]{2}{*}{ Normal Parameters ${ }^{a . b}$} & \multicolumn{2}{|l|}{ Mean } & .0000000 \\
\hline & \multicolumn{2}{|l|}{ Std. Deviation } & 4.13702536 \\
\hline \multirow[t]{3}{*}{ Most Extreme Differences: } & \multicolumn{2}{|l|}{ Absolute } & .076 \\
\hline & \multicolumn{2}{|l|}{ Positive } & .043 \\
\hline & \multicolumn{2}{|l|}{ Negative } & -.076 \\
\hline \multicolumn{3}{|l|}{ Test Statistic } & .076 \\
\hline \multicolumn{3}{|l|}{ Asymp. Sig (2-tailed) } & $.037^{\mathrm{c}}$ \\
\hline \multirow{3}{*}{$\begin{array}{l}\text { Monte Carlo Sig. (2- } \\
\text { tailed) }\end{array}$} & \multicolumn{2}{|l|}{ Sig. } & $339^{d}$ \\
\hline & \multirow[t]{2}{*}{$99 \%$ Confidence interval } & Lower Bound & 327 \\
\hline & & Upper Bound & 351 \\
\hline \multicolumn{4}{|c|}{ a. Test distribution is Normal. } \\
\hline \multicolumn{4}{|l|}{ b. Calculated from data. } \\
\hline \multicolumn{4}{|c|}{ c. Lilliefors Significance Correction. } \\
\hline \multicolumn{4}{|c|}{ d. Based on 10000 sampled tables with starting seed 334431365 . } \\
\hline
\end{tabular}

Pada Uji Multikolonieritas, Nilai cut-off adalah nilai Tolerance $\geq 0,10$ yaitu 0,661 atau dan VIF $\leq 10$ (Ghozali, 2011). Pada uji ini, VIF memiliki nilai 1,512 atau kurang 10 sehingga tidak ditemukan adanya masalah multikolinieritas.

Tabel 4.

Uji Multikolinieritas

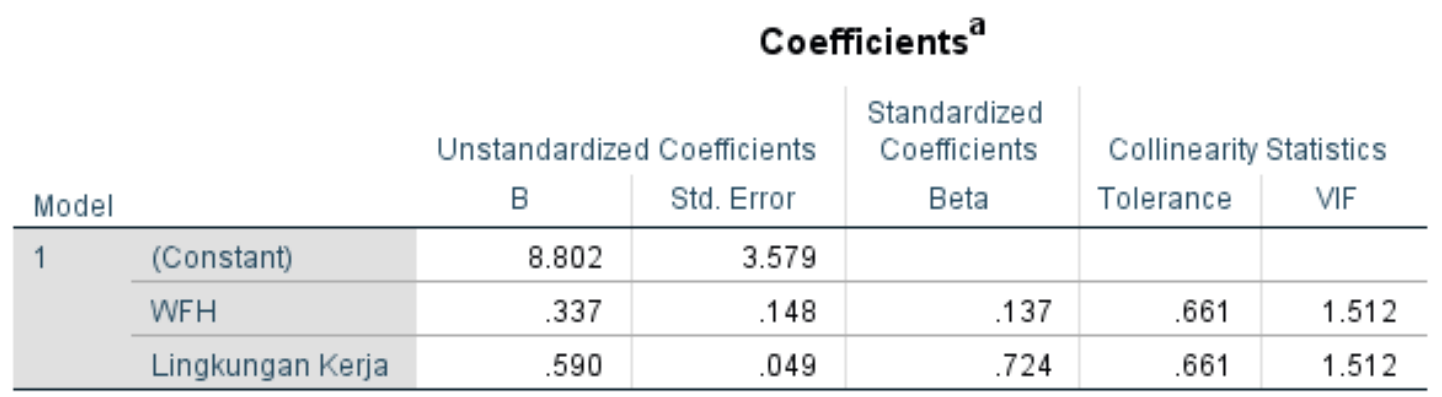

a. Dependent Variable: Produktivitas Kerja

Pada Uji Heteroskedasitas mengukur ketidaksamaan varian dan residual (Ghozali, 2011). Selain bisa menggunakan scatter-plot dengan melihat titik-titik yang menyebar 
dalam gambar, uji ini dapat menggunakan Spearman's rho untuk mengukur adanya korelasi masing-masing variable dengan menggunakan unstandardized residual.

Tabel 5.

Uji Heteroskedastisitas

\begin{tabular}{|c|c|c|c|c|c|}
\hline & & Correlations & WFH & $\begin{array}{l}\text { Lingkungan } \\
\text { Kerja }\end{array}$ & $\begin{array}{l}\text { Unstandardiz } \\
\text { ed Residual }\end{array}$ \\
\hline \multirow[t]{9}{*}{ Spearman's tho } & \multirow[t]{3}{*}{ WFH } & Correlation Coefficient & 1.000 & $.362^{*}$ & .085 \\
\hline & & Sig. (2-tailed) & . & .000 & .304 \\
\hline & & $N$ & 148 & 148 & 148 \\
\hline & \multirow[t]{3}{*}{ Lingkungan Kerja } & Correlation Coefficient & $.362^{* \prime}$ & 1.000 & -.144 \\
\hline & & Sig. (2-tailed) & .000 & . & .081 \\
\hline & & $\mathrm{N}$ & 148 & 148 & 148 \\
\hline & \multirow[t]{3}{*}{ Unstandardized Residual } & Correlation Coefficient & .085 & -.144 & 1.000 \\
\hline & & Sig. (2-tailed) & .304 & .081 & . \\
\hline & & $N$ & 148 & 148 & 148 \\
\hline
\end{tabular}

${ }^{\star *}$. Correlation is significant at the 0.01 level (2-tailed).

Pada output correlations diatas, WFH dengan Unstandardized Residual sig. (2tailed) sebesar 0,304 dan Lingkungan Kerja sig. (2-tailed) sebesar 0,081 dan disimpulkan tidak terjadi masalah heterokedastisitas karena memiliki nilai sig. diatas 0,05.

Tabel 6.

Uji Parsial (t-test)

\begin{tabular}{|c|c|c|c|c|c|c|}
\hline & & \multicolumn{5}{|c|}{ Coefficients $^{a}$} \\
\hline & & \multicolumn{2}{|c|}{ Unstandardized Coefficients } & \multirow{2}{*}{$\begin{array}{c}\text { Standardized } \\
\text { Coefficients } \\
\text { Beta }\end{array}$} & \multirow[b]{2}{*}{$\mathrm{t}$} & \multirow[b]{2}{*}{ Sig. } \\
\hline \multicolumn{2}{|c|}{ Model } & $\mathrm{B}$ & Std. Error & & & \\
\hline \multirow[t]{3}{*}{1} & (Constant) & 8.802 & 3.579 & & 2.460 & .015 \\
\hline & WFH & .337 & .148 & .137 & 2.284 & .024 \\
\hline & Lingkungan Kerja & .590 & .049 & .724 & 12.108 & .000 \\
\hline
\end{tabular}

a. Dependent Variable: Produktivitas Kerja

a. Dari tabel 6 di atas yaitu Work From Home $\left(X_{1}\right)$ memiliki nilai sig. 0,00<0,05 ( $\alpha$ sig) dan t-hit 2,284 > t-tabel 1,976 sehingga ada pengaruh Work From Home $\left(\mathrm{X}_{1}\right)$ terhadap produktivitas pegawai (Y).

b. Lingkungan kerja $\left(\mathrm{X}_{2}\right)$ memiliki nilai sig. 0,00<0,05( $\alpha$ sig) dan t-hit 12,108 $>$ t-tabel 1,976 yaitu adanya pengaruh yang signifikan Lingkungan Kerja $\left(X_{2}\right)$ terhadap produktivitas pegawai $(Y)$. 
Dari hasil di atas persamaan regresi linier bergandanya yaitu $Y=8,802+0,337 X_{1}+$ $0,590 \mathrm{X}_{2}$.

Tabel 7.

Uji F - Simultan

\begin{tabular}{|c|c|c|c|c|c|c|}
\hline \multicolumn{7}{|c|}{ ANOVA $^{a}$} \\
\hline Model & & Sum of Squares & df & Mean Square & $\mathrm{F}$ & Sig. \\
\hline \multirow[t]{3}{*}{$\overline{1}$} & Regression & 4828.767 & 2 & 2414.384 & 139.149 & $.000^{b}$ \\
\hline & Residual & 2515.902 & 145 & 17.351 & & \\
\hline & Total & 7344.669 & 147 & & & \\
\hline a. D & ent Variabl & duktivitas Kerja & & & & \\
\hline
\end{tabular}

Secara simultan baik variable Work From Home (WFH) atau $\mathrm{X}_{1}$ dan Lingkungan Kerja $\left(\mathrm{X}_{2}\right)$ berpengaruh signifikan terhadap Produktivitas kerja pegawai $(Y)$, nilai signifikansi $0,00<0,05$ dan untuk $F$ hitung $>F$ tabel yaitu $F$ hitung sebesar 139,149 > 3,06 .

Mengukur kemampuan model untuk menerangkan varian dari variable terikat dapat menggunakan Koefisien determinasi $\left(R^{2}\right)$ (Kuncoro, 2010). Koefisien Determinasi $\left(R^{2}\right)$ didapat 0,657 atau $65,70 \%$ dengan pengertian adanya pengaruh variabel bebas baik $X_{1}$ dan $\mathrm{X}_{2}$ memiliki nilai $65,70 \%$ terhadap variabel terikat $\mathrm{Y}$, sisanya $34,30 \%$ adalah variable yang tidak diteliti. Variabel lain yang dapat diteliti untuk menemukan korelasi dapat menggunakan kepuasan kerja, motivasi kerja dan pengawasan kerja, beban kerja selama masa pandemi ini. Dengan menggunakan variable bebas dan terikat tersebut dapat diukur korelasi antar masing-masing variable

Tabel 8.

\section{Koefisien Determinasi}

\begin{tabular}{|c|c|c|c|c|c|}
\hline \multicolumn{6}{|c|}{ Model Summary } \\
\hline Model & $\mathrm{R}$ & R Square & $\begin{array}{l}\text { Adjusted R } \\
\text { Square }\end{array}$ & $\begin{array}{l}\text { Std. Error of } \\
\text { the Estimate }\end{array}$ & $\begin{array}{l}\text { Durbin- } \\
\text { Watson }\end{array}$ \\
\hline 1 & $.811^{\mathrm{a}}$ & .657 & .653 & 4.165 & 1.422 \\
\hline
\end{tabular}

a. Predictors: (Constant), Lingkungan Kerja, WFH

b. Dependent Variable: Produktivitas Kerja 


\section{Pengaruh Work From Home (WFH) Terhadap Produktivitas Kerja Pegawai Pemerintah Kota Bekasi Dinas Perumahan Kawasan Pemukiman dan Pertanahan}

Adanya pengaruh secara positif dan signifikan antara WFH terhadap produktivitas kerja pegawai Pemerintah Kota Bekasi Dinas Perumahan Kawasan Pemukiman dan Pertanahan ditunjukkan denganl T-hitung $>$ T-tabel yaitu $(2,284>1,976)$ sig. $0,000<0,05$ (Ho ditolak dan Ha diterima) dengan penjelasan bahwa Work From Home secara signifikan berpengaruh terhadap produktivitas kerja pegawai. Salah satu indikator WFH adalah gangguan stress. Adanya gangguan stress karena pegawai dihadapkan pada pekerjaan yang membutuhkan deadline, sementara pegawai memiliki interaksi yang terbatas terhadap atasan apabila ada pertanyaan untuk pekerjaannya. Untuk itu, diperlukan monitoring berupa progress pengerjaan pegawai agar sesuai arahan atasan. Pada penelitian ini dapat disimpulkan karyawan. Riset ini diperkuat dengan peneliti sebelumnya yaitu (Simarmata, 2020), yang menyatakan bahwa WFH berpengaruh positif dan signifikan terhadap produktivitas kerja.

\section{Pengaruh Lingkungan Kerja Terhadap Produktivitas Kerja Pegawai Pemerintah Kota Bekasi Dinas Perumahan Kawasan Pemukiman dan Pertanahan}

Ada pengaruh positif yang signifikan lingkungan kerja terhadap produktivits kerja Pegawai Pemerintah Kota Bekasi Dinas Perumahan Kawasan Pemukiman dan Pertanahan. Hasil uji t-hitung < t-tabel $(12,108<1,976)$, sig. $0,000<0,05$ berarti Ho ditolak, Ha diterima dengan penjelasan lingkungan kerja berpengaruh positif dan signifikan terhadap produktivitas kerja. Salah satu indikator lingkungan kerja di rumah adalah kebersihan ruangan atau perilaku penghuni. Kebersihan ruangan bekerja di rumah dengan di kantor terasa berbeda karena di kantor kebersihan dilakukan secara menyeluruh dengan adanya petugas khusus yang menanganinya. Disimpulkan bahwa apabila terjadi kenaikan lingkungan kerja maka akan terjadi kenaikan produktivitas kerja. Hasil ini diperkuat oleh peneliti sebelumnya yaitu (Massoudi \& Hamdi, 2017). Ada hubungan antara lingkungan kantor dengan produktivitas karyawan sehingga menimbulkan kepuasan karyawan terhadap Lingkungan tempat kerja secara keseluruhan mengarah pada produktivitas.

\section{E. KESIMPULAN}

Kesimpulan yang dapat ditarik dari penelitian di atas adalah :

1. Work From Home $\left(\mathrm{X}_{1}\right)$ secara signifikan berpengaruh positif terhadap Produktivitas pegawai (Y) di pemerintahan daerah kota Bekasi. Apabila terjadi peningkatan Work from home maka akan berpengaruh positif terhadap produktifitas kerja. Bekerja pada tempat tinggal sendiri membuat kedekatan secara psikologi antara pekerja dengan anggota kelauarga. Hampir semua karyawan merasakan adanya waktu yang terbatas karena bekerja di kantor dibandingkan di rumah, dengan adanya gangguan wabah ataupun gangguan lainnya yang memaksa pegawai untuk berada di wilayah lingkungan keluarga.

2. Lingkungan tempat Kerja $\left(X_{2}\right)$ secara signifikan memiliki pengaruh yang positif terhadap Produktivitas pegawai $(\mathrm{Y})$ pemda kota Bekasi. Peningkatan Lingkungan tempat Kerja yang positif akan meningkatan produktivitas pegawai. Lingkungan kerja di rumah memberikan dampak positif yang signifikan terhadap produktivitas kerja 
pegawai pemda kota Bekasi. Lingkungan tempat kerja di rumah membuat pegawai merasa lebih nyaman apabila suasana rumah yang mendukung untuk bekerja.

3. Secara bersamaan (simultan) variabel Work from home (WFH) $\left(\mathrm{X}_{1}\right)$ dan Lingkungan Kerja dirumah $\left(\mathrm{X}_{2}\right)$ pada pegawai di pemerintahan kota Bekasi berpengaruh secara signifikan terhadap Produktivitas Pegawai (Y).

4. Variabel dominan dalam penelitian ini adalah Lingkungan Kerja $\left(\mathrm{X}_{2}\right)$ dibandingkan dengan Work From Home atau WFH $\left(\mathrm{X}_{1}\right)$.

Sebagai tindak lanjut untuk penelitian berikutnya agar melakukan penelitian pada variable pengawasan kerja, kepuasan kerja, motivasi kerja selama masa pandemi ini agar dapat dilihat perbandingan pada pencapaian hasilnya. Sedangkan untuk mengawasi pekerjaan selama Work From Home agar produktivitas kerja tetap stabil atau meningkat, dapat dilakukan melalui instruksi pimpinan untuk mewajibkan pegawai tidak mematikan laptop selama jam kerja agar dapat diketahui produktivitas masing-masingnya. Pada lingkungan kerja di rumah, pimpinan dapat mewajibkan pegawai mengerjakan tugasnya pada tempat atau ruangan yang nyaman, bersih dan tidak bising.

\section{DAFTAR PUSTAKA}

Al-Shammari, D. S. A. (2013). The Effect of Work Environment on Employees' Productivity. International Journal of Science and Research (IJSR), Vol 4(5 May 2015), 1554. https://ijsr.net/archive/v4i5/SUB154560.pdf

Bloom, N. (2014). To raise productivity, let more employees work from home. In Harvard Business Review.

Chandrasekar, K. (2011). Workplace environment and its impact on organisational performance in public sector organisations. International Journal of Enterprise Computing and Business Systems.

Dictionary. (n.d.). Dictionary.com. https://www.dictionary.com/browse/wfh

Dingel, J. I., \& Neiman, B. (2020). How many jobs can be done at home? Journal of Public Economics. https://doi.org/10.1016/j.jpubeco.2020.104235

Farrell, K. (2017). Working From Home: A Double Edged Sword. Home Renaissance Foundation Conference, 16-17 Nov, 8. https://doi.org/https://doi.org/10.21427/kk4be646

Ghozali, I. (2011). Aplikasi Analisi Multivariate Dengan Program SPSS 19. Edisi Kelima Semarang : Bandan Penerbitan Universitas Diponegoro.

Huselid, M. A. (2018). The Impact Of Human Resource Management Practices On Turnover, Productivity, And Corporate Financial Performance. Academy of Management Journal. https://doi.org/10.5465/256741

Jain, R., \& Kaur, S. (2014). Impact of Work Environment on Job. International Journal of Scientific and Research Publications.

No.

829/Menkes/SK/VII

Tahun 1999. https://peraturan.bkpm.go.id/jdih/userfiles/batang/KEPMENKES_829_1999.pdf 
Kuncoro, mudrajad. (2010). Metode kuantitatif: teori dan aplikasi untuk bisnis dan ekonomi. In System.

Massoudi, D. A. H., \& Hamdi, D. S. S. A. (2017). The Consequence of work environment on Employees Productivity. IOSR Journal of Business and Management, 19(01), 3542. https://doi.org/10.9790/487X-1901033542

Mulyadi. (2001). edisi 3. Akuntansi manajemen, Konsep, Manfaat, dan Rekayasa. In Universitas Gadjah Mada.

Nitisemito, A. S. (2013). Manajemen Personalia (Manajemen Sumber Daya Manusia) (Cetakan VI). Ghalia Indonesia.

Raziq, A., \& Maulabakhsh, R. (2015). Impact of Working Environment on Job Satisfaction. Procedia Economics and Finance. https://doi.org/10.1016/s2212-5671(15)00524-9

Saleh, A. R. (2018). Pengaruh Disiplin Kerja, Motivasi Kerja, Etos Kerja Dan Lingkungan Kerja Terhadap Produktivitas Kerja Karyawan Bagian Produksi Di PT Inko Java Semarang. Among Makarti.

Sauermann, J. (2016). Performance measures and worker productivity. IZA-World of Labor. $\quad$ https://wol.iza.org/uploads/articles/260/pdfs/performance-measures-andworker-productivity.pdf

Siagian, S. P. (2014). Manajemen Sumber Daya Manusia. Bumi Aksara.

Simarmata, R. M. (2020). Pengaruh Work From Home Terhadap Produktivitas Dosen Politeknik Negeri Ambon. Intelektiva: Jurnal Ekonomi, Sosial \& Humaniora, Vol 2 No.1(E-ISSSN 2686

https://jurnalintelektiva.com/index.php/jurnal/article/view/265

5661).

Sinaga, S., \& Ibrahim, M. (2016). Pengaruh Lingkungan Kerja Terhadap Produktivitas Kerja Karyawan (Bagian Produksi Minyak Kelapa Sawit Pt. Mitra Unggul Pusaka Segati Pelalawan Riau). JOM FISIP Universitas Riau, Vol 3 No 2. https://www.neliti.com/publications/33206/pengaruh-lingkungan-kerja-terhadapproduktivitas-kerja-karyawan-bagian-produksi

Sunardi, N., \& Lesmana, R. (2020). Konsep Icepower (Wiramadu) sebagai Solusi Wirausaha menuju Desa Sejahtra Mandiri (DMS) pada Masa Pandemi Covid19. JIMF (Jurnal IImiah Manajemen Forkamma), 4(1).

Wikipedia. (n.d.-a). Definisi Rumah. In Wikipedia. https://id.wikipedia.org/wiki/Rumah\#: :text=Dalam arti umum\%2C rumah adalah,sangkar\%2C sarang $\% 2 \mathrm{C}$ atau kandang.

Wikipedia. (n.d.-b). Digital. https://id.wikipedia.org/wiki/Digital 